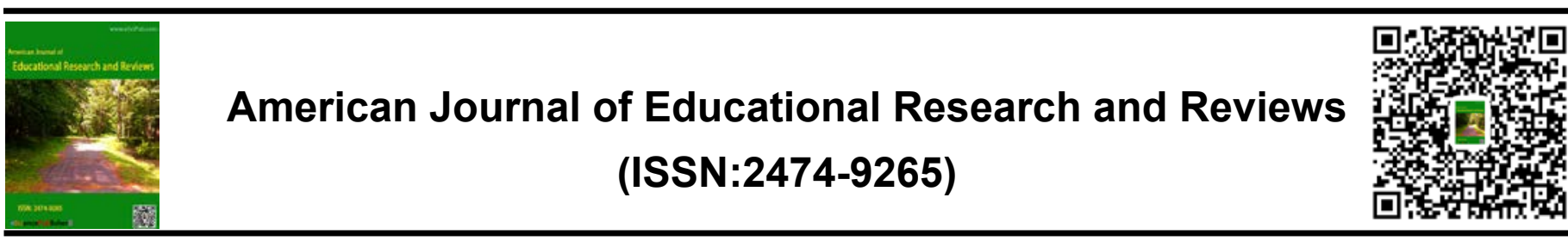

\title{
Nutrition Attitudes and Information Levels of Football Referees
}

\author{
${ }^{1}$ ibrahim Muhammed Salih IBRAHIM, ${ }^{1}$ Hayri DEMiR, ${ }^{2}$ Mehmet ALTIN
}

*1 Selcuk University, Faculty of Sports Sciences, Sports Management Department Konya / Turkey

2 Selçuk University, Faculty of Sports Sciences, Recreation Department Konya/Turkey

\section{ABSTRACT}

This study aims at revealing the changes in nutrition attitude and knowledge levels of football referees. 130 referees actively serving as Candidate, Provincial and Regional Referees in Izmir, Konya, Aksaray and Niğde provinces constituted the sample group of the study. The personal information form was used in obtaining the socio-demographic information, and the nutrition knowledge and attitude scale developed by Ertürk (2010) was used in determination of the nutrition attitude and knowledge. The variance and homogeneity of the data were tested, "Independent Samples t Test" was used for binary comparisons, "One Vay Anowa" for differences between groups in multiple comparisons, and "Tukey" test for the determination of variation sources. The nutritional attitudes of the provincial and district referees were higher than those of the candidate referees and the nutritional information of the candidate referees were higher than the provincial and district referees and this change was statistically found to be significant $(P<0.05)$. While no change due to the gender factor was observed, nutrition information of the referees received nutrition lessons was found to be higher than the referees who did not, and this change was statistically found to be significant $(P<0.05)$. No difference was found in nutritional attitudes and knowledge of the referees depending on factors such as age, income, sibling, years of service, and level of education. As a result, it can be said that candidate referees who have just started their duties have more nutrition knowledge than provincial and district referees, and provincial and district referees have better nutrition attitudes than candidate referees. Football referees are thought to be an important issue in renewing their nutritional attitudes and knowledge in order to improve their performance and quality of life.

Kewords: Football Referee, Nutrition Knowledge, Nutrition Attitude
*Correspondence to Author: Mehmet ALTIN

Selçuk University, Faculty of Sports Sciences, Recreation Department Konya/Turkey

How to cite this article:

İbrahim Muhammed Salih IBRAHIM,Hayri DEMIR, Mehmet ALTIN. Nutrition Attitudes and Information Levels of Football Referees. American Journal of Educational Research and Reviews, 2018,3:13.

\section{eSciencePublisher 8}

eSciPub LLC, Houston, TX USA. Website: http://escipub.com/ 


\section{INTRODUCTION}

The more influential the cultural values of a society are in societal lifestyles, the more effective is the eating and drinking habits (Shar, 2013). The concept of nutrition comes in many different definitions and classifications in the literature. Baysal (2007) defined nutritional concepts as behaviors which must be consciously made to receive nutritional items necessary for the body to maintain, heal, improve the health and enhance quality of life, in adequate and balanced quantities and at appropriate times. Nutrition concept is often used with the same meanings as adequate and balanced nutrition concepts. The reason for this is that nutrition consists of a deeper sense more than just feeding or saturating sense. Adequate and balanced nutrition is also expressed as adequate intake and proper use of each of the nutritional items required for growth and development (Alpural 2009). Healthy diet means to meet all nutrients needed in sufficient quantities taking the age, gender and physiological state of the individual into account. Nutrition is necessary for growth, development, survival and protection of health (Saygın et al., 2011).

In addition to maintain our vital activities and the fulfillment of our basic needs, one of the greatest problems of our time is immobility and obesity. It is reported in WHO (the World Health Organization) (2012) that the mortality due to inactivity and obesity has increased. Even a simple timeframe, which we will devote to movement and exercise activities in any part of our daily lives, will be very beneficial for our bodies. Kokino and Zateri (2000) studied the mortality rates of people who are weak and overweight with sedentary and exercising, and emphasized that death rates are twice as high as those who are overweight and exercising, although they are weak in sedentary people. Many technological innovations that make our life easier have also opened the doors of laziness, inactivity and antisocial experience. In addition to all these, an irregular unbalanced eating habit towards ready-to-eat food has become a great threat in the society sense. Sporty activities are a factor that increases our quality of life together with planned, programmed correct nutrition attitude, knowledge and habit. Sport is an activity that requires adequate and balanced feeding, along with appropriate training methods. Ersoy (2004) reported that a properly fed athlete will have a desirable level of fatty and lean body composition, and that biochemical parameters important for overall health status and performance will remain within normal limits.

Nowadays it is possible to encounter quite different individual and team sports. Depending on the type of sport being made, nutrition knowledge, habits and attitudes differ. Ersoy and Hasbay (2008) reported that it is necessary to control the athletes who are at higher risk of developing a nutritional problem more frequently (requiring more than two hours of continuous and non-stop activity, requiring endurance) and, when necessary, individualization and modification of their nutrition programs would be appropriate. Before, during and after the exercise, adequate and balanced nutrition is effective in regulation of blood glucose level, enhancement of exercise performance and acceleration of the recovery process. The energy requirement for the sportsmen can be calculated by adding the daily physical activity (taking the type, intensity and duration of exercise into account) to the basal metabolic rate (the energy wasted at the time of absolute rest after digestion of the received food) (Ersoy and Hasbay 2008). In addition to the equilibrium of the amount of energy taken and the amount of energy consumed, proper and balanced eating habits serve to a healthy and quality lifestyle. The characteristics of sportive activity and sports branches are important factors affecting the amount of energy consuming, diet style and attitudes. In urgent and short-term activities, energy needs are met by ATP. ATPphosphocreatine and lactic acid are produced 
in long-acting and anaerobic-requiring activities. The energy requirement varies depending on sex, age, body size and composition, type of exercise, severity and frequency. The energy requirements of the athlete are higher than those of the non-athlete (Burke and Collier 2000). Referee TDK (2017) is defined as the person whom the parties chose as the competent authority to resolve the dispute between them, the person whom they agreed on, the judge, the person who understands a particular subject, the person who has the authority to make selections and decisions, and conducts the sports matches and competitions objectively conforming to the guidelines. Different criteria and physical measurement tests are used in order to be a football referee (Instructions of Central Referee Committee of Turkish Football Federation www.tff.org.t). Football with the difference of being a team sport, it is a diet that can be eaten collectively and followed easily by considering the principle of individuality with the help of dietician and defeated collectively. The football referees have to have mental and physical capacity as well as football-playing athletes, and it will be an appropriate behavior to follow their own nutrition attitudes and habits.

Table 1. Daily average energy intake recommended for elite athletes and distribution of macro nutrient items in percentage (Burke and Collier 2000).

\begin{tabular}{|c|c|c|}
\hline Type of Sport & Daily Energy & Nutrients \\
\hline Basketball & $5200 \mathrm{kcal}$ & $54 \%$ cho- $18 \%$ prt- $28 \%$ fat \\
\hline Handball & $5400 \mathrm{kcal}$ & $54 \%$ cho- $18 \%$ prt- $28 \%$ fat \\
\hline Football & 55 & $54 \%$ cho- $18 \%$ prt- $28 \%$ fat \\
\hline Wrestling & 5400 & $50 \%$ cho- $20 \%$ prt- $30 \%$ fat \\
\hline Swimming $(1000 \mathrm{~m})$ & e & $52 \%$ cho- $18 \%$ prt- $30 \%$ fat \\
\hline Volleyball & $5000 \mathrm{kcal}$ & $52 \%$ cho- $18 \%$ prt- $30 \%$ fat \\
\hline Tennis & $5200 \mathrm{kcal}$ & $54 \%$ cho- $18 \%$ prt- $28 \%$ fat \\
\hline Athletics & $6200 \mathrm{kcal}$ & $56 \%$ cho- $16 \%$ prt- $28 \%$ fat \\
\hline Cross & $6200 \mathrm{kcal}$ & $60 \%$ cho- $15 \%$ prt- $25 \%$ fat \\
\hline
\end{tabular}

While there are a lot of sources about the nutrition knowledge, attitudes and habits of the athletes; there is a very limited study in the literature regarding referees' nutritional knowledge and attitudes. It is observed that the individuals who are regarded as former athletes and left sports predominantly prefer refereeing in our country. The football, which has become an industry and spends billions of dollars, is entrusted to the referees who have been trained with limited opportunities but are still under great responsibility. Refereeing is a field of work that requires a great deal of responsibility and effort to be a profession alone. Without nutritional knowledge, it is not possible to move our attitudes and habits to the appropriate level without nutrition knowledge. In order to have basic nutrition knowledge, attitudes and behaviors of all individuals, especially those who serve the sports field, it is thought that it would be beneficial to carry out such studies repeatedly with different examples.

\section{MATERIAL AND METHOD}

130 referees actively serving as Candidate, Provincial and Regional Referees in Izmir, Konya, Aksaray and Niğde provinces constituted the sample group of the study. The personal information form was used in obtaining the socio-demographic information and the nutrition knowledge and attitude scale 
developed by Ertürk (2010) was used in determination of the nutrition attitude and knowledge. The "Likert Scale" was used in the evaluation of the part about the nutrition knowledge and attitude of the test. This scale is a measure to determine the individual behavior scores of a subject. Different number of options is determined for each of the $\mathrm{K}$ problems. The options are ranged in sequential order. On this scale, a score of +2 is given to those who are absolutely agree with the right information and attitudes, $+\mathbf{1}$ to the ones agree, 0 to those who are not sure, -1 to those who do not agree, and -2 for the ones who are not absolutely agree
(136). The questionnaire used in our research has 27 questions about nutrition knowledge and 11 suggestions about attitude. The maximum nutrition information score is set at 54 and the attitude score at 22 in case they answer all proposals correctly. Variance and homogeneity of the data was tested and independent samples $t$ test was used for binary comparisons, One vow Anowa was used for determining differences between groups in multiple comparisons, and the Tukey test was used for identifying differences.

Table 1. Nutritional Attitudes and Knowledge Exchanges of Referees by Area, Gender and Nutrition Education Status

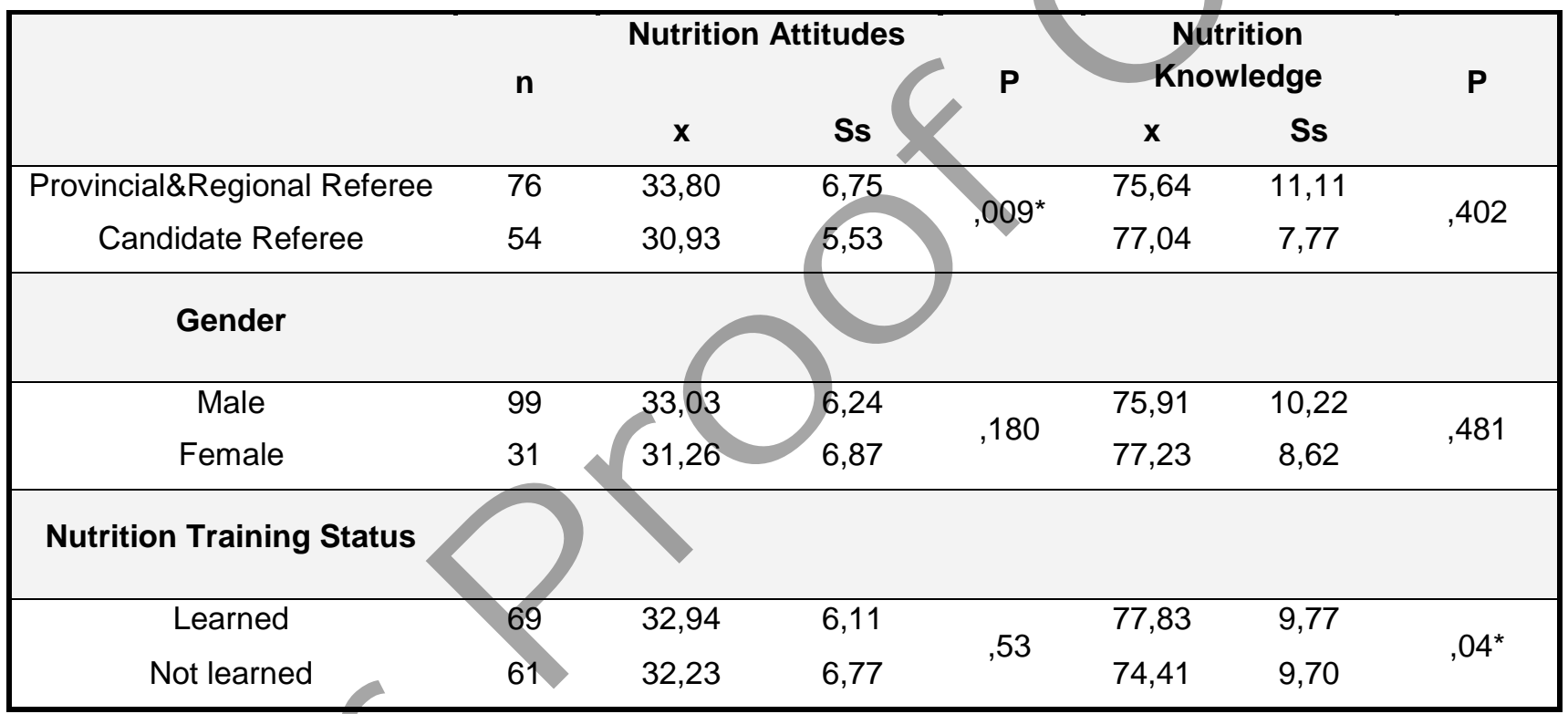

"Significant difference between groups.

\section{FINDINGS}

As seen in Table 1, it was determined that the average of the nutrition attitudes of the provincial and regional football referees $(33,8 \pm$ $6,75)$ is higher than the average of the candidate referees $(30,93 \pm 5,53)$, and this change is found to be statistically significant $(P<0.05)$. No statistical difference between provincial and regional and nutritional knowledge of candidate referees was determined.

The nutritional attitudes and knowledge values of women was observed to be higher than that of men, but this change was found not to be statistically significant. While there was no difference in the nutritional attitudes of referees who had and did not receive nutrition classes, nutrition information $(77,83 \pm 9,77)$ of referees who got nutrition course was found higher than the average of referees who did not have nutrition course $(74,41 \pm 9,70)$, and the change was statistically found to be significant ( $P$ $<0.05$ ). As is seen in Table 2, no statistically significant difference was observed between Age, Income, Sibling, Sports Service Year and Nutrition Attitudes and Information according to 
Education Levels of the provincial and regional referees and candidate Referees; $(P>0.05)$.

Table 2. Nutritional Attitudes and Information Changes According to Factors of Age, Income, Sibling, Sports Service Year and Education Level factor of Referees

\begin{tabular}{|c|c|c|c|c|c|c|c|}
\hline \multirow{3}{*}{ Age Levels } & \multirow{3}{*}{$\mathbf{n}$} & \multicolumn{2}{|c|}{ Nutrition Attitude } & \multirow{3}{*}{$\mathbf{P}$} & \multirow{2}{*}{\multicolumn{2}{|c|}{$\begin{array}{c}\text { Nutrition } \\
\text { Knowledge }\end{array}$}} & \multirow{3}{*}{$\mathbf{P}$} \\
\hline & & \multirow[b]{2}{*}{$x$} & \multirow[b]{2}{*}{ Ss } & & & & \\
\hline & & & & & $\mathbf{x}$ & Ss & \\
\hline $18-25$ years & 35 & 33,77 & 5,65 & \multirow{4}{*}{,475 } & 77,97 & 10,07 & \multirow{4}{*}{,273 } \\
\hline $26-33$ years & 37 & 31,38 & 6,03 & & 75,65 & 10,59 & \\
\hline $34-41$ years & 28 & 32,71 & 5,89 & & 77,61 & 6,88 & \\
\hline 42 years and over & 30 & 32,67 & 8,03 & & 73,60 & & \\
\hline \multicolumn{8}{|l|}{ Income Level (TL) } \\
\hline $1000-2000$ & 33 & 33,42 & 6,50 & & 77,79 & 9,53 & \multirow{4}{*}{, 536} \\
\hline $2001-3000$ & 29 & 32,07 & 7,09 & & & 9,40 & \\
\hline $3001-4000$ & 45 & 31,71 & 6,84 & & 74,60 & 10,51 & \\
\hline 4001 and over & 23 & 33,87 & 4,15 & & 7,00 & 9,67 & \\
\hline \multicolumn{8}{|l|}{ Number of Siblings } \\
\hline No Siblings & 22 & 31,41 & 5,28 & \multirow{5}{*}{, 575} & 77,32 & 6,95 & \multirow{5}{*}{,413 } \\
\hline 1 Sibling & 27 & 32,96 & 7,21 & & 78,15 & 9,94 & \\
\hline 2-3 Siblings & 42 & 31,86 & 6,66 & & 75,05 & 10,70 & \\
\hline 4-5 Siblings & 23 & 33,65 & 6,71 & & 77,35 & 8,66 & \\
\hline 6 and over Siblings & 16 & 34 & 5,38 & & 72,94 & 12,10 & \\
\hline \multicolumn{8}{|l|}{ Education Level } \\
\hline Primary School & 18 & 30,61 & 7,31 & \multirow{5}{*}{,640 } & 75,94 & 7,91 & \multirow{5}{*}{,227 } \\
\hline Secondary School & 23 & 33,78 & 4,04 & & 77,74 & 7,42 & \\
\hline High School & 39 & 32,67 & 6,63 & & 77,49 & 10,26 & \\
\hline University & 34 & 32,82 & 7,66 & & 72,94 & 11,98 & \\
\hline Master/ Doctorate & 16 & 32,56 & 4,63 & & 78,25 & 7,98 & \\
\hline \multicolumn{8}{|c|}{ For how long dealing with sports } \\
\hline $0-5$ years & 26 & 33,19 & 5,43 & & 74,15 & 9,39 & \multirow{5}{*}{,496 } \\
\hline $6-10$ years & 34 & 33,00 & 6,63 & & 75,74 & 11,09 & \\
\hline $11-15$ years & 33 & 32,21 & 6,02 & ,228 & 76,97 & 9,81 & \\
\hline $16-20$ years & 14 & 35,21 & 5,44 & & 79,93 & 10,90 & \\
\hline 21 years and over & 23 & 30,35 & 7,80 & & 75,96 & 7,68 & \\
\hline
\end{tabular}

\section{DISCUSSION CONCLUSION}

This study aims to reveal the changes between the nutrition knowledge and attitudes of football referees. The nutritional attitudes of the provincial and district referees were found to be higher than the candidate referees and the nutrition knowledge of the candidate referees were higher than the provisional and regional 
referees and this change was statistically found to be significant (Table 1, $\mathrm{P}<0.05$ ). The literature is quite limited in terms of the researches directed to the referees. Renon and Collado (2015) reported that football referees had an incomplete dietary intake of carbohydrates in their study of eating habits, thus indicating a decrease in referee performance. In the same study, they emphasized the importance of referees receiving nutrition education. The results of our research with Renon and Collado (2015) are significant in terms of similarity. Decisions of referees in suddenly developing situations are of great importance in terms of their compliance with the conscience as well as the rule. In the football industry, the monetary base is largely hidden above the social well-being. Factors that we can count not only footballers but also the trainers, analysts, commentators, the dealers based around the stadium, hotels, food sector, transportation, betting companies and more consist the quantitative part of the soccer industry. The referees are among the invisible directors and most influential elements of this sector and industrial structure. In a study Teixeira and his friends (2014) conducted on eating habits of the elite football referees, they reported that their fluid intake was very low and they did not get sufficient amounts of carbohydrates in the next period before they went out to the field and said they would be eligible to take nutrition lessons. Changes in nutrition knowledge and attitudes of referees in our study are similar to this study. It is important for referees to be able to make the right decisions rapidly; carbohydrate foods that are ready and can be used quickly are the first foods to be preferred in the first plan. The important thing is that we have enough knowledge to get what we need from all the food items. It will be appropriate for the referees to include activities related to nutrition habits, attitudes and information in in-service training courses and seminars. While no change due to the gender factor was observed in our study, nutrition knowledge of the referees who received the nutrition course was found higher than the ones who did not take nutrition courses and this change was statistically found to be significant $(P<0.05)$. In the literature, the studies indicating that women have higher nutritional habits and behaviors than men are seen to be more (Ayhan et al., Şanlıer et al., 2009; Vançelik et al., 2007). This can be seen as the role and status that the society prescribes to men and women depending on the reasons and cultural transfers. In our study, it was determined that nutrition information of female referees was higher than males and nutritional attitudes were lower (Table 1). It shapes an opinion that the level of knowledge the female referees is not reflected in their attitudes. Ulaş and Genç (2010) pointed out that different education programs and strategies on health nutrition should be developed by emphasizing that individuals will not be sufficient if they do not reflect on the behaviors of their rightful knowledge. If the nutritional information will remain as written in books and diet programs and not used, it will remain as a surplus which will not positively serve the quality of life of an individual. Çetin and Sarper (2013) reported that medical school education had a positive effect on students' nutritional knowledge levels. Programmed and systematic nutrition education is a factor that increases the quality of life of the individuals and positively affects their performance. Demirezen and Coşansu (2005) found out serious risks threatening the adolescents' lives in the case of nutritional habits in them in their studies in which they used BAI (Nutrition Habits Index) and reported that men were in a more risky condition. In the same study; it is also emphasized on the importance of assessing eating habits and the need for school-based health education programs to promote healthy eating habits. Türk et al. (2007) reported that pupils had adequate knowledge of food, but frequently included unhealthy appetite in their diets. Özmen et al. (2007) observed that skipping meals in high school students is a common f-educational-research-and-reviews/ 
eating habit and that many adolescents do not eat regular meals three times a day.

In this study; no difference in nutritional attitudes and knowledge depending on factors such as age, income, sibling, years of service, and level of education was found. There are different findings and conclusions about nutritional status depending on sociodemographic factors in the literature. A number of factors such as education level, age, familial status and income can affect nutrition attitude knowledge and habit. The most important thing to keep in mind is that we can do anything wrong even if we know it is wrong with the behaviors such as time problems, ignorance, seeing as a correctable element.

When football is supported in the future by digital technology-enhanced materials, the prospect will be further increased and it will be among the professions of the future. Our study is in terms of being an example of studies related to football refereeing that are not seen as a profession in our country and whose educational level is determined only as seminars and development courses. Nutrition is not just about the nutrients that we put in our mouths when it comes to our minds each time, but the concept of adequate and balanced nutrition should be able to make a positive impact on the quality of life that is internalized by athletes.

Based on the findings of these studies; it can be said that the candidate referees who took office newly have more nutrition knowledge than the provincial and district referees and the provincial and district referees have better nutrition attitudes than the candidate referees. Football referees are expected to renew their nutritional attitudes and knowledge in order to improve their performance and quality of life, and to provide nutritional habits for nutrition education that they will receive from the specialist dietitians.
Alpural NS (2009) Sağlıklı Beslenme Kavramı ve Eğitmenlerin Algısı Üzerine Bir Araştırma, Yüksek Lisans Tezi, Ankara, pp:7-8

Ayhan DE, Günaydın E, Gönlüaçık E, Arslan U, Çetinkaya F, Asımı H, Uncu Y (2012) Uludağ Üniversitesi Tıp Fakültesi Öğrencilerinin Beslenme Alışkanlıkları ve Bunları Etkileyen Faktörler, Uludağ Üniversitesi Tıp Fakültesi Dergisi 38 (2) 97-104, 2012 97.

Baysal A.(2007). Beslenme. (11. bs.). Ankara: Hatiboğlu Yayınevi.

Burke, LM., Collier, GR. (2000). Energy requirement of resistance exercise. J Am Diet Assos, 100, 154356.

Çetin G, Sarper F (2013) Tıp Fakültesi Birinci ve Son Sınıfa Devam Eden Öğrencilerin Beslenme Bilgi ve Alışkanlıkları Üzerine Bir Araştırma, 21. Yüzyılda Eğitim ve Toplum, Cilt 2 Sayı 6.

Demirezen E, Coşansu G (2005) Adölesan Çağı Öğrencilerde Beslenme Alışkanlıklarının Değerlendirilmesi, STED, cilt 14, sayı 8, s; 174.

Ersoy, G. (2004). Egzersiz ve Spor Yapanlar için Beslenme. Ankara: Nobel Yayınları.

Ersoy G, Hasbay A (2008) Sporcu Beslenmesi, Ankara: T.C Sağlık Bakanlığı Temel Sağlık Hizmetleri Genel Müdürlüğü ve Fiziksel Aktiviteler Daire Başkanlığı Yayını.

Ertük Ş (2010) Üniversite atletizm takımına seçilen 18-22 yaş gurubu erkek öğrencilerin, beslenme bilgi,tutum ve alışkanlıklarının, vücut bileşimleri ve hemoglobin düzeylerinin performanslarına etkisi üzerine bir araştırma, Hacettepe Üniversitesi, Sağlık Bilimleri Enstitüsü, Beslenme ve Diyetetik Anabilim Dalı, Doktora tezi, Ankara.

Http://turkdilkurumu.com (TDK) Erişim 2017

Kokino S, Zateri C (2000). Obezite ve aerobik egzersizler. Türkiye Klinikleri Tıp Bilimleri Dergisi. 4,91-99.

Özmen D, Çetinkaya AÇ, Ergin D, Şen N, Erbay PD (2007) Lise Öğrencilerinin Yeme Alışkanlıkları ve Beden Ağırlığını Denetleme Davranışları, TSK Koruyucu Hekimlik Bülteni, 6 (2), 98-105.

Renon CM, Collado PS (2015) An assessment of the nutritional intake of soccer referees, Journal of the International Society of Sports Nutrition, 12:8.

Saygın M, Öngel K, Çalışkan S, Yağı MA, Has M, Gonca T, Kurt Y (2011) Süleyman Demirel Üniversitesi öğrencilerinin beslenme alışkanlıkları, S.D.Ü. Tıp Fak. Dergisi, 18(2)/43-47

Şanlıer N, Konaklıoğlu E, Gücer E (2009) Gençlerin Beslenme Bilgi, Alışkanlık ve Davranısları Ile Beden

\section{RESOURCES}


Kütle İndeksleri Arasındaki İlişki, GÜ, Gazi Egitim Fakültesi Dergisi, Cilt 29, Sayı 2 (2009) 333-352.

Şar S (2013) "Tarihi Süreç İçerisinde Türk Mutfak Kültürüne Kısa Bir Bakış" Lokman Hekim Journal 2013; Supplement VIII. Lokman Hekim Days 22 - 25 May 2013 Ninth Session: Poster Session.

Teixeira VH, Gonçalves L, Meneses T, Moreira P (2014) Nutritional intake of elite football referees, Journal of Sports Sciences, Vol. 32, No. 13, 12791285 .

Türk M, Gürsoy ŞT, Ergin I (2007) Kentsel bölgede lise birinci sınıf öğrencilerinin beslenme alışkanlıkları, Genel Tıp Derg, 17(2).

Ulaş B, Genç MF (2010) Malatya Asker Hastanesinde 2007 Yılında Görev Yapan Personelin Sağlıklı Beslenme Konusundaki Tutum ve Davranışları, İnönü Üniversitesi Tıp Fakültesi Dergisi, 17 (3) 187-193.

Vançelik S, Önal SG, Güraksın A, Beyhun E ( 2007) Üniversite Öğrencilerinin Beslenme Bilgi ve Alışkanlıkları ile İlişkili Faktörler, TSK Koruyucu Hekimlik Bülteni, 2007: 6 (4), 242-248.

WHO (2012) 1.Health status indicators. 2.World health. 3.Health services - statistics. 4.Mortality. 5.Morbidity. 6.Life expectancy. 7.Demography. 8.Millennium development goals - statistics. 9.Statistics. I.World Health Organization. ISBN 97892 41564441 (NLM classification: WA 900.1) 